\title{
A CONTABILIDADE GERENCIAL NAS MICRO E PEQUENAS EMPRESAS DO COMÉRCIO DE CONFECÇÕES DA CIDADE DE TANGARÁ DA SERRA - MT
}

\author{
César Luís Souto Olyntho ${ }^{1}$ \\ Adervaldo Chaves Ribeiro ${ }^{2}$ \\ Eder Eugenio Munhão ${ }^{3}$
}

\section{RESUMO}

Este artigo teve como objetivo demonstrar a percepção dos gestores de Micro e Pequenas Empresas (MPE's) do ramo de confecções da cidade de Tangará da Serra - MT a respeito da Contabilidade Gerencial na tomada de decisões. A Contabilidade Gerencial está voltada para os gestores da empresa, sendo uma ferramenta necessária e útil para auxiliar na tomada de decisão, com o objetivo de gerar informações necessárias para o sucesso da entidade. $\mathrm{O}$ método utilizado é a pesquisa descritiva, por se tratar de uma abordagem a uma amostra de população. A obtenção dos dados foi através de aplicação de questionário, por meio de pesquisa in loco nas próprias empresas. Nos resultados foram identificados que os gestores das MPE's apesar de dizerem que são usuários da Contabilidade Gerencial, em sua maioria ainda não dispõem do conhecimento necessário para usá-la. Foi possível conhecer as características dos gestores e das empresas pesquisadas. A pesquisa concluiu que a maior parte das MPE's não se utiliza da Contabilidade Gerencial para tomada de decisão, porém através da pesquisa bibliográfica foi orientado como a Contabilidade Gerencial pode melhorar o desempenho da empresa.

Palavras-chave: Contabilidade Gerencial; Gestores; MPE's.

\section{INTRODUÇÃO}

O presente trabalho objetivou demonstrar que, apesar da Contabilidade Gerencial ter sido criada a princípio para grandes instituições e indústrias, suas informações fornecidas são de grande valor também para as MPE's, tornando-se um diferencial nesse mercado cada vez mais competitivo, e o que pode resultar na sobrevivência ou extinção dela (LAURENTINO et al. 2008).

A Contabilidade Gerencial é uma ferramenta técnica e complexa de modo a dificultar sua inserção nas MPE's. De acordo com Almeida (apud Kassai, 1997), não é extremamente importante nas MPE's, que seus gestores tenham um vasto conhecimento de técnicas como a Contabilidade Gerencial para garantir uma boa gestão, tendo em vista a simplicidade de funcionamento de sua administração. O que realmente é importante são as adaptações às

\footnotetext{
1 Acadêmico do curso de Ciências Contábeis da UNEMAT - Campus de Tangará da Serra, e-mail: cesar.souto@r7.com

${ }^{2}$ Mestre em Gestão de Empresa, Professor do curso de Ciências Contábeis da UNEMAT - Campus de Tangará da Serra, e-mail: adervaldoribeiro@gmail.br

${ }^{3}$ Mestrando em Ciências Contábeis do Minter UNISINOS/UNEMAT, e-mail: edermunhao@unemat.br
} 
teorias e práticas conhecidas, desenvolvidas e executadas nas grandes empresas para a realidade, necessidade e capacidade das MPE's.

Historicamente o Brasil sempre teve internacionalmente seu reconhecimento como grande produtor de produtos primários, relacionados à agricultura e mais recentemente com a pecuária, por essa razão não teve um grande destaque em seu setor industrial. Diante dessa posição, as MPE's passaram a ocupar um papel relevante na economia nacional e que até hoje é um dos pilares que sustentam o país. (SEBRAE, 2007).

As MPE's expandiram-se em todo o Brasil, aproveitando-se das características regionais para consolidarem-se no mercado local, em especial, na industrialização de produtos hortifrutigranjeiros e no setor de comércio, sobretudo nos relacionados ao setor têxtil. (SCHEFFER; CARIO; NICOLAU, 2005).

Para Barros (apud Lacerda, 2006, p. 42), as funções que a pequena empresa exerce como contribuição ao processo evolutivo do país, por exemplo:
a) A significativa contribuição na geração do Produto Nacional;
b) A excelência na absorção de grande contingente da mão-de-obra a baixo custo;
c) A sua alta flexibilidade locacional, desempenhando importante papel na interiorização do desenvolvimento;
d) A capacidade de gerar uma classe empresarial nacional, através da absorção de uma tecnologia gerencial produzida em seu próprio ambiente;
e) A possibilidade de atuação no comércio exterior, proporcionando uma salutar diversificação na pauta de exportações;
f) A sua condição de ação complementar aos grandes empreendimentos.

A competitividade entre as empresas brasileiras está cada vez mais acirrada, haja vista a ascensão econômica brasileira, que exigirá dos gestores um conhecimento mais técnico e um maior domínio de práticas gerenciais em seu dia a dia. De Acordo com Laurentino et al. (2008), diante das constantes mudanças e aumentos na competitividade entre as empresas brasileiras, surge a importância de adotar de técnicas de gestão especializadas. Na realidade brasileira, entretanto, as MPE's, por se tratarem de empresas pequenas, em muitos casos são comandadas através da gestão familiar, no entanto esse tipo de administração tem a característica de não compreender a importância de gerir seu negócio com técnicas administrativas modernas e assim tornam-se despreparadas para o mercado (SOUZA, 2011).

Além disso, as dificuldades aumentam na medida em que o fluxo de informações necessárias para uma boa gestão fica maior e mais complexo.

É importante ressaltar que constantemente o mercado passa por mudanças, que surgem e obrigam o gestor a se adequar a elas, mudanças essas que afetam direta e indiretamente o seu comércio. Com uma demanda de clientes cada vez mais exigentes, dá ao 
gestor uma responsabilidade de buscar ainda mais o domínio de técnicas que lhe auxiliem em sua gestão. A Contabilidade Gerencial vem com esse propósito, de melhorar a tomada de decisões de seus usuários.

Segundo Chiletto (2009) a cidade de Tangará da Serra - MT se apresenta como a sexta economia de Mato Grosso, muito bem estruturada tanto em agroindústrias como em seu comércio. Tangará é o $10^{\circ}$ maior PIB (Produto Interno Bruto) mato-grossense, com um total de $\mathrm{R} \$ 846.326,00$, totalizando 2,29\% em todo o Estado no ano de 2004. Também tem um dos maiores orçamentos (R 102 milhões/ano) do interior do Estado. A sua condição é de município pólo de uma região com potencial sócio econômico emergente.

De acordo com esse panorama de comércio forte e promissor, entre inúmeros ramos de atuação, este projeto destacou o de confecções, haja vista a quantidade de empresas, que de acordo com dados da prefeitura municipal existem 116 em funcionamento, dados de 2012. Com isso a importância de uma pesquisa que busque a utilização da Contabilidade Gerencial para esse ramo específico, objetivando uma melhoria em sua administração, não só em benefício da empresa, mas também de toda uma microeconomia local.

Este artigo objetivou contribuir para uma mudança na visão gerencial dos gestores das empresas do comércio de confecção da cidade de Tangará da Serra - MT, pois a contabilidade aliada de práticas gerenciais dá ao gestor mais embasamento para o processo decisório das empresas, atingindo então uma visão gerencial melhor.

Neste contesto surge a seguinte questão: As empresas do varejo de confecção na cidade de Tangará da Serra - MT se utilizam da Contabilidade Gerencial no processo decisório em seu cotidiano?

Para Silva (2007) as MPE's, pela sua própria estrutura, precisam ainda mais de instrumentos gerenciais relevantes, para que o gestor tenha um grau maior de segurança em suas decisões, e isso possibilite a realização de ações compatíveis com a demanda existente dentro da organização, medida que pode ser vital para que a entidade se mantenha atuante no mercado e não venha a falir precocemente, mesmo havendo oscilações externas. Dessa forma, o conhecimento das práticas gerenciais em um sentido amplo, serve de amparo para tais empresas, preparando-as, em certa medida, para enfrentar o cenário econômico atual.

Segundo Souza (2011 p. 4) "o atual cenário da economia nacional revela que a maioria dos empreendimentos formais do Brasil é constituída de micros e pequenas empresas, o que faz com que sejam consideradas pilares de sustentação dos negócios". O mesmo autor demonstra que, segundo uma pesquisa realizada pelo Departamento 
Intersindical de Estatística e Estudos Socioeconômicos (DIEESE), em parceria com o Serviço Brasileiro de Apoio às Micro e Pequenas Empresas (SEBRAE), publicada no Anuário do Trabalho na MPE em 31 de Agosto de 2010, a participação das MPE’s apenas no cenário de estabelecimentos formais em atuação no Brasil corresponde a 99,0\% dos 5,8 milhões e empregam 52,3\% dos 24,9 milhões de trabalhadores fora da informalidade, ou seja, com a carteira de trabalho assinada. Isso corresponde a 13,1 milhões de empregados. Em virtude da grande capacidade de gerar empregos e riquezas julga-se um importante elo de contribuição significativa para o crescimento do PIB.

Segundo Silva (2007 p. 2).

A Contabilidade Gerencial surge como alternativa significativa para o micro ou pequeno empresário. Este pode contar com um sustentáculo gerencial em sua empresa, principalmente pelo fato da Contabilidade já estar sendo realizada no interior da organização, em face à situação gerada pela legislação existente no país. Com isso, ao optar pela Contabilidade Gerencial, o gestor dessas organizações consegue ter acesso a um instrumento que pode colaborar com a gestão, em decorrência das informações que é capaz de gerar e interpretar, resultando no fornecimento de relatórios adequados a sua necessidade, podendo, assim, amparar o processo decisório. (grifo nosso)

O objetivo da pesquisa foi comparar dentre as MPE's do ramo de confecções na cidade de Tangará da Serra - MT, as que atuam utilizando a Contabilidade Gerencial como uma ferramenta para tomada de decisão, as que não se utilizam desta ferramenta. Como objetivo especifico: 1. Identificar dentre as MPE's do ramo de confecções da cidade de Tangará da Serra - MT, as empresas que utilizam a Contabilidade Gerencial como fonte para seu processo decisório. 2. Verificar que tipo de informações fornecidas pela Contabilidade Gerencial aplica-se aos micro e pequenos empreendimentos. 3. Traçar o perfil dos gestores das empresas de confecções de Tangará da Serra - MT comparando seu gerenciamento com as decisões sugeridas pela Contabilidade Gerencial. 4. Analisar se a Contabilidade Gerencial pode ser ferramenta de ampliação da eficácia e da eficiência na gestão das micro e pequenas empresas.

\section{REFERENCIAL TEÓRICO}

\subsection{Contabilidade Gerencial}

De acordo com Padoveze (2000, p.27),

A Contabilidade Gerencial é definida como um processo de identificação, mensuração, acumulação, análise, preparação, interpretação e comunicação de informações (financeiras e operacionais) utilizadas pela administração para planejar, avaliar e controlar internamente uma organização e avaliar o uso de seus recursos, assim contabilizá-los. 
A contabilidade gerencial nas micro e pequenas empresas do comércio de confecções da cidade de

Tangará da Serra - MT

César Luís Souto Olyntho; Adervaldo Chaves Ribeiro; Eder Eugenio Munhão

Para Souza, (2012, p. 7)

A Contabilidade Geral pode ser conceituada como a ciência que, por meio de suas técnicas e procedimentos, controla e registra atos, movimentações e fatos ocorridos no patrimônio da empresa em um determinado período de tempo, sejam estes mercadorias, dinheiro, serviços, créditos, etc. À medida que esses dados são coletados e mensurados, informações estratégicas valiosíssimas começam a florescer. Tais informações constituem o primordial objetivo da Contabilidade: subsidiar ao empresário suporte firme para tomada de decisões com maior segurança e eficácia.

A Contabilidade Gerencial tem papel importante na evolução das necessidades de controles, que evoluíram de acordo com a complexidade das operações, em cada organização. Neste sentido, Contabilidade Gerencial tem a necessidade de se consolidar como importante instrumento de controle e está para atender as práticas decisórias das empresas. Por outro lado, constata-se a existência de baixa aderência da implantação e melhoria das técnicas contábeis e de conceitos de Contabilidade Gerencial nas empresas (SOUZA; LISBOA; ROCHA. 2003; GUERREIRO et al., 2005).

Na visão de Francia et al. (1992, p. 4):

Contabilidade Gerencial é o processo de identificação, mensuração, acumulação, análise, preparação, interpretação e comunicação de informações financeiras utilizadas pela administração para planejamento, avaliação e controle dentro de uma organização e para assegurar e contabilizar o uso apropriado de recursos.

De acordo com o quadro 1, podemos ter uma visão um pouco mais simples das atribuições da Contabilidade Gerencial, e também a forma em que ela pode ser inserida diretamente na entidade.

QUADRO 1 - Características da Contabilidade Gerencial

\begin{tabular}{|l|l|}
\hline \multicolumn{1}{|c|}{ CARACTERÍSTICA } & \multicolumn{1}{c|}{ DESCRIÇÃO } \\
\hline USUÁRIOS & Administradores de vários níveis da organização \\
\hline LIBERDADE DE ESCOLHA & $\begin{array}{l}\text { Nenhuma restrição além dos custos em relação aos benefícios } \\
\text { de melhores decisões administrativas. }\end{array}$ \\
\hline IMPLICAÇÕES COMPORTAMENTAIS & $\begin{array}{l}\text { Preocupação com a forma pela qual as medidas e os relatórios } \\
\text { influenciarão o comportamento diário dos administradores. }\end{array}$ \\
\hline ENFOQUE DO TEMPO & $\begin{array}{l}\text { Orientação para o futuro, uso formal de orçamentos e registros } \\
\text { históricos. }\end{array}$ \\
\hline PRAZO & Flexível, variando de uma hora para dez ou quinze anos. \\
\hline RELATÓRIOS & $\begin{array}{l}\text { Detalhados; preocupação com detalhes de partes de entidade, } \\
\text { produtos, departamentos, territórios etc. }\end{array}$ \\
\hline DELINEAMENTO DAS ATIVIDADES & $\begin{array}{l}\text { O campo é definido com menos precisão. Maior uso de } \\
\text { economia, ciências de decisão e ciências do comportamento. }\end{array}$ \\
\hline
\end{tabular}

FONTE: SOUZA, 2008, p. 25.

Já para Iudícibus (1991, p.15): 
A Contabilidade Gerencial pode ser caracterizada, superficialmente, como um enfoque especial conferido a várias técnicas e procedimentos contábeis já conhecidos e tratados na contabilidade financeira, na contabilidade de custos, na análise financeira e de balanços, etc., colocados numa perspectiva diferente, num grau de detalhe mais analítico ou numa forma de apresentação e classificação diferenciada, de maneira a auxiliar os gerentes das entidades em seu processo decisório.

Segundo Atkinson et al. (2000) a Contabilidade Gerencial é citada por vários autores como tendo uma grande participação na administração de qualquer entidade, principalmente para o resultado direto da administração, pois suas ferramentas permitem uma rápida e objetiva interpretação dos números da empresa. Assim, a Contabilidade Gerencial poderá executar o seu papel de gerar informações ao empresário para que este tome decisões mais acertadas e em tempo hábil.

Na visão de Atkinson et al. (2000, p. 45)

\begin{abstract}
A Contabilidade Gerencial possui quatro funções especificas para a entidade, que são elas: 1) o controle operacional, fornecendo informações (feedback), retorno das tarefas executadas de acordo com a qualidade e eficiência; 2) custeio do produto e do cliente mensurando os custos dos recursos para se produzir, vender e entregar um produto ou serviço aos clientes e transforma-los em números para o gerenciamento; 3) controle administrativo, fornecendo informações sobre o desempenho de gerentes e de unidades operacionais; e 4) controle estratégico fornecendo informações sobre o desempenho financeiro e competitivo de longo prazo, condições de mercado, preferências dos clientes e inovações tecnológicas. A utilidade da Contabilidade Gerencial e o nível de satisfação dos gestores estão, dessa forma, associados ao cumprimento dessas funções.
\end{abstract}

Para Silva (2007) a Contabilidade Gerencial tem plenas condições de colaborar no desenvolvimento da empresa, tendo em vista que quando se considera o fato de todas as organizações necessitarem realizar a Contabilidade tradicional, atendendo aos ditames da lei. Com isso, o emprego da Contabilidade Gerencial pode ser facilitado, desde que o gestor demonstre interesse em modificar sua postura no tocante ao gerenciamento da organização.

\title{
2.2 Gerentes e Gestores
}

Segundo Ching; Marques; Prado (2003), de forma que o trabalho no interior da instituição ocorra de uma forma efetiva, há necessidade de que os gestores tenham facilidade nas informações a respeito da variedade de recursos envolvidos e utilizados. Sem um fluxo dinâmico e eficiente de informações úteis, a empresa não terá possibilidade de atuar seguramente no dia a dia empresarial. É primordial para os gestores uma base firme que subsidie importantes informações que contribuam para efetivação de suas decisões em todos os departamentos da empresa. 
A contabilidade gerencial nas micro e pequenas empresas do comércio de confecções da cidade de

De acordo com Crepaldi (2008) é correto afirmar que em via de regra, as MPE's normalmente são administradas pelos próprios sócios, que têm formação técnica ligada ao seu negócio, mas sem a concepção administrativa de gestão (administração, finanças, economia, marketing), ou seja, até entendem a "parte prática" de seu negócio, mas deixam a desejar em sua administração, o que tem levado a um grande número de falências, recuperações judiciais e encerramento das pequenas empresas nos seus primeiros anos de vida. (Grifo do autor)

“Assim, diante da importância da Contabilidade Gerencial para as ME's e EPP's, cabe observar quais são as ferramentas (práticas gerenciais) que a Contabilidade Gerencial pode utilizar para auxiliar os gestores no processo de tomada de decisão” (MOTA; REGO 2006 p. $5)$.

A Contabilidade Gerencial é uma ferramenta fundamental na empresa e tem o importante suporte aos gerentes no cumprimento de suas atribuições, no que concernem as atividades de planejamento, direção, movimentação e controle. Assim sendo, a Contabilidade Gerencial é uma ferramenta que está conjugada à necessidade interna, à otimização dos resultados futuros, enfatizando sempre os segmentos específicos de cada empresa (SOUZA 2008).

Para que o gestor de uma MPE permaneça forte no mercado, é importante que o gestor adote um controle de sua estrutura financeira, estratégica, comercial, etc, sendo o uso da informação a ferramenta mais apropriada para tal.

Lucena et al. (2004, p. 21) defende essa ideia afirmando que:

Gerenciar uma empresa seja ela grande ou pequena, exige que as pessoas à frente destas organizações se deparem, a todo o momento, com escolhas, assim fica evidente que as informações bem utilizadas levarão a empresa ao sucesso. Muitas vezes há uma informação simples, com uma repercussão incrível, em outros casos, há uma busca numa infinidade de dados que não geram nenhuma informação, ou quando geram já não se caracterizam relevantes.

Segundo pesquisa que o SEBRAE (2007) realizou entre período de 2003-2005 abordando os fatos determinantes e taxas de sobrevivência e mortalidade das micro e pequenas empresas no Brasil, e nesse estudo constatou-se que uma das razões primaria para o fechamento das empresas, está centrada no bloco de falhas gerenciais, pois das empresas destacando-se: ponto/local inadequado, falta de conhecimentos gerenciais e desconhecimento do mercado, seguida de causas econômicas. Em relação à mesma pesquisa, outros fatores que se destacaram para motivar o fechamento das empresas relacionam-se direta ou 
indiretamente, com o papel das informações contábeis e a sua utilização por parte do empreendedor.

De acordo com Panucci-Filho; Almeida (2011) A maturidade de gestão como abordagem compartimentada em períodos, conhecidos como estágios, tem por objetivo sistematizar a compreensão do processo evolutivo das organizações. Conceitualmente se atribui níveis com características definidas em cada dimensão que se identificam durante o ciclo de vida organizacional. A preocupação desse mecanismo é compreender a longevidade da organização.

Diante disso, Panucci-Filho; Almeida (2011, p. 6), complementam a respeito da maturidade de gestão.

\begin{abstract}
A maturidade de gestão surge como o conjunto de práticas e processos intercalados que contribuem para a consolidação dos propósitos da organização. E ao avanço progressivo por meio de ações baseadas em adaptação e ajustes ao meio ambiente que a organização está inserida, resulta no seu crescimento e sobrevivência, por meio das diversas fases de aprendizado.
\end{abstract}

\title{
2.3 Micro e Pequenas Empresas
}

A Lei Geral para Micro e Pequenas Empresas (LC 123/2006, atualizada pela LC $\mathrm{n}^{\circ}$. 139/2011), conforme disposto no artigo $3^{\circ}$ da Lei Geral, consideram-se microempresas ou empresas de pequeno porte, a sociedade empresária, a sociedade simples e o empresário individual devidamente registrado na Junta Comercial do Estado ou no Cartório de Registro das Pessoas Jurídicas, conforme o caso, desde que as Microempresas aufiram, em cada anocalendário, receita bruta igual ou inferior a $\mathrm{R} \$ 360.000,00$; e as pequenas aufiram, em cada ano-calendário, receita bruta superior a $\mathrm{R} \$ 360.000,00$ e igual ou inferior a $\mathrm{R} \$ 3.600 .000,00$.

Não há no mundo uma unanimidade no que se refere à conceituação e classificação das MPE's, pois cada país adota formas particulares e de acordo com suas realidades de mercado (SALES; SOUZA NETO, 2004). No Brasil, as MPE's são definidas pelo Estatuto da Microempresa e Empresa de Pequeno Porte (Lei $n^{\circ}$ 9.841/99) e pelo SIMPLES (Lei $n^{\circ}$ 9.317/96), que utilizam como forma de classificação, a receita bruta anual. Por sua vez, o SEBRAE também usa uma classificação das empresas, onde é considerada uma ME no ramo de comércio ou serviços aquela que tem de 0 a 9 funcionários; já para MPEs e indústrias o número aumenta para 10 a 49 funcionários. As EPP do setor de comércio e serviços, a quantidade de funcionários pode variar de 0 a 19 e já para indústria o número é de 20 a 99 funcionários. 
A contabilidade gerencial nas micro e pequenas empresas do comércio de confecções da cidade de

\title{
2.4 Comércio Varejista
}

A definição de comércio varejista consiste principalmente na venda de produtos em pequenas quantidades que serão repassados diretamente ao consumidor final, sem nenhum outro intermediador.

Para Salim et al., (2005, p. 7),

\begin{abstract}
A venda a VAREJO é aquela em que o fornecedor vende diretamente ao consumidor final em quantidades geralmente pequenas, para seu próprio consumo. Ou seja, a empresa de varejo procura atender a um consumidor que compra para uso próprio. Esse consumidor não repassa a terceiros, como forma de negócio, qualquer parcela de quantidade comprada.
\end{abstract}

Segundo Parente (2007, p. 22) varejo consiste em "todas as atividades que englobam o processo de venda de produtos e serviços para atender uma necessidade pessoal do consumidor final". O mesmo autor acrescenta ainda que o varejista é "qualquer instituição cuja atividade principal consiste no varejo, isto é, na venda de produtos e serviços para o consumidor final".

A maioria das pessoas tem uma ideia superficial em relação ao varejo, pois imaginam logo várias lojas, camelôs e estabelecimentos aglomerados em ruas, avenidas etc., mas isso vai além do tamanho da loja ou a forma que ocorre a venda, seja em loja ou não (por telemarketing, internet, revistas), o importante é a concretização da venda para o consumidor final, isso define uma atividade varejista (KOTLER; ARMSTRONG, 1998).

\section{METODOLOGIA}

Segundo Vergara (2007, p. 47): “a pesquisa empírica é o estudo que se refere a instrumentos de captação ou de manipulação da realidade. Está, portanto, associada a caminhos, formas, maneiras, procedimentos para atingir determinado fim".

A pesquisa foi realizada no comércio varejista de confecções da cidade de Tangará da Serra/MT, durante o segundo semestre de 2012. A população total do estudo corresponde a 116 empresas de acordo com cadastro junto à prefeitura municipal. No entanto, a pesquisa foi realizada com 32 (trinta e duas) empresas localizadas na Av. Brasil, por ser um grande centro comercial local, onde a maioria das empresas de confecção está instalada. Realizou-se uma amostra não probabilística por acessibilidade.

O período pesquisado nas empresas foi de 2012, por todo o questionário basear suas questões em informações atuais, e assim pode demonstrar um resultado mais próximo da realidade. 
A pesquisa de campo é a investigação de um determinado fenômeno em seu determinado ambiente de ocorrência. "Desenvolvida principalmente nas ciências sociais, a pesquisa de campo é aquela em que o pesquisador, através de questionários, entrevistas, protocolos verbais, observações, etc., coleta seus dados, investigando os pesquisados no seu meio" (PRESTES, 2003, p. 27).

Como instrumento de pesquisa foram aplicados questionários, Kotler (1998, p. 121) afirma que,

O questionário consiste de um conjunto de questões para serem respondidas por questionados. Em função de sua flexibilidade, é o instrumento mais comum para coletar dados primários. Precisam ser cuidadosamente desenvolvidos, testados e corrigidos antes de serem administrados em larga escala.

Através do questionário o projeto buscou respostas fundamentais, para assim responder aos questionamentos e objetivos propostos. O questionário elaborado foi composto por perguntas mistas, com questões abertas e de múltipla escolha, que quantificarão os itens resultantes da pesquisa.

O tipo da pesquisa foi a descritiva por se tratar de uma abordagem a uma amostra de população com questionário. Ocorrerá juntamente uma pesquisa explicativa, pois foi abordado de uma forma mais substancial os dados obtidos no final da pesquisa e analisado seus resultados.

A pesquisa foi do tipo descritiva, com abordagem quantitativa, para o instrumento de coleta de dados foi utilizado um questionário misto semiestruturado que procura investigar variáveis relacionadas às características do gestores, características das empresas e características das práticas empresariais de gestão.

\section{RESULTADOS}

Foram aplicados questionários mistos em 32 (trinta e duas) Micro e Pequenas Empresas do ramo de confecções na cidade de Tangará da Serra - MT. Todas contribuíram com a pesquisa. O objetivo foi avaliar a utilização da Contabilidade Gerencial nas MPE's no seu processo decisório.

Foi questionado aos gestores das MPE's, sobre o tempo de atividade das empresas. Segue a Gráfico 1, que representa a porcentagem dos períodos de início das atividades da empresa. 
A contabilidade gerencial nas micro e pequenas empresas do comércio de confecções da cidade de Tangará da Serra - MT

César Luís Souto Olyntho; Adervaldo Chaves Ribeiro; Eder Eugenio Munhão

Gráfico 1. Há quanto tempo a empresa iniciou suas atividades?

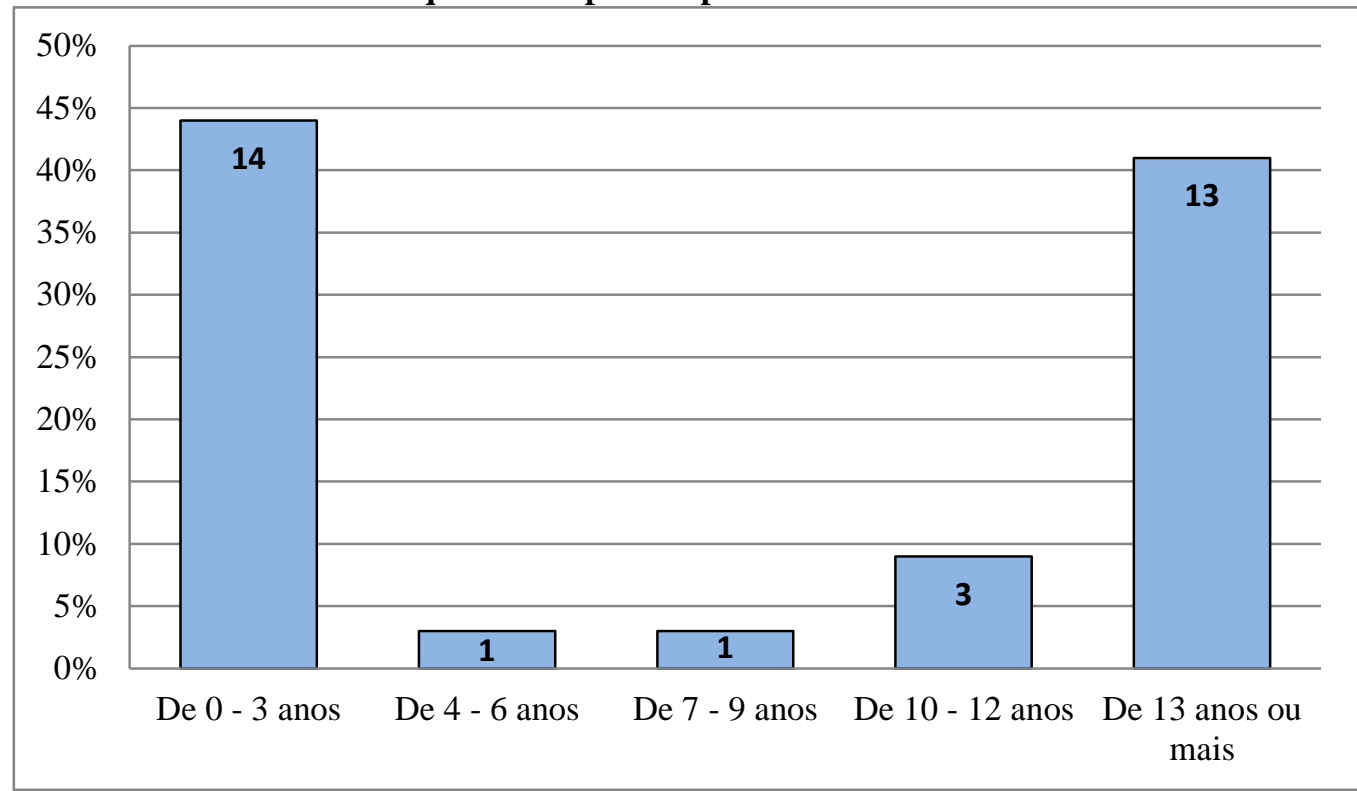

Fonte: Dados da Pesquisa

Foi analisado que 44\% que é representado por 14 (quatorze) gestores das MPE's tem entre $0-3$ anos no mercado. 50\% dos entrevistados, ou seja, dezesseis gestores, estão atuando a mais de 10 (dez) anos, nota-se que, ou a empresa recentemente iniciou suas atividades e busca espaço nesse mercado, ou ela já é uma empresa consolidada que atua a muitos anos nesta atividade.

O gráfico 2 representa a gestão das MPE's do ramo de confecções, pesquisadas.

Gráfico 2. Quem é responsável (eis) pela administração da empresa?

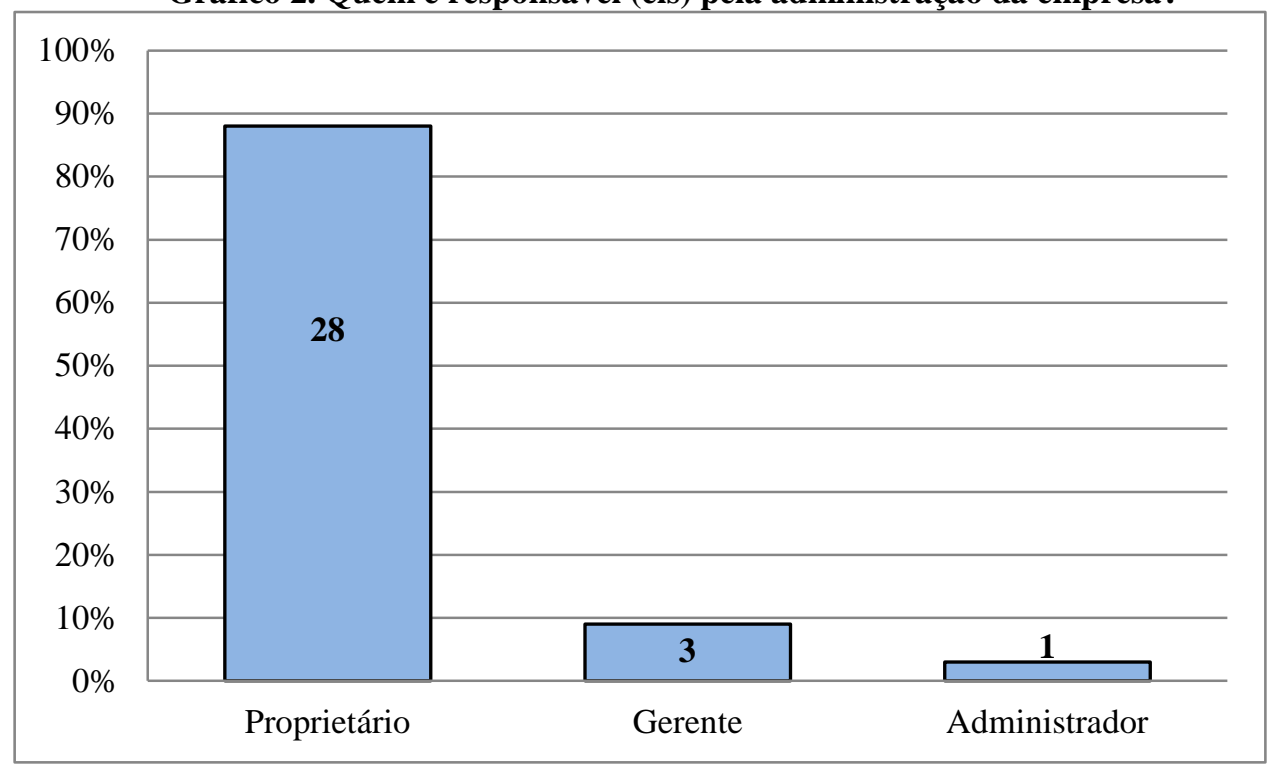

Fonte: Dados da Pesquisa 
A contabilidade gerencial nas micro e pequenas empresas do comércio de confecções da cidade de Tangará da Serra - MT

César Luís Souto Olyntho; Adervaldo Chaves Ribeiro; Eder Eugenio Munhão

Quanto ao perfil dos gestores pesquisados, identificou-se que a grande maioria, 28 (vinte e oito) deles são proprietários, o que representa $88 \%$ do total de pesquisados, 4 (quatro) deles são denominados como gerentes ou administradores, o que equivale a $12 \%$.

Segue o Gráfico 3, onde foi questionado sobre o grau de escolaridade dos responsáveis.

Gráfico 3. Qual o grau de escolaridade do(s) responsável (eis)?

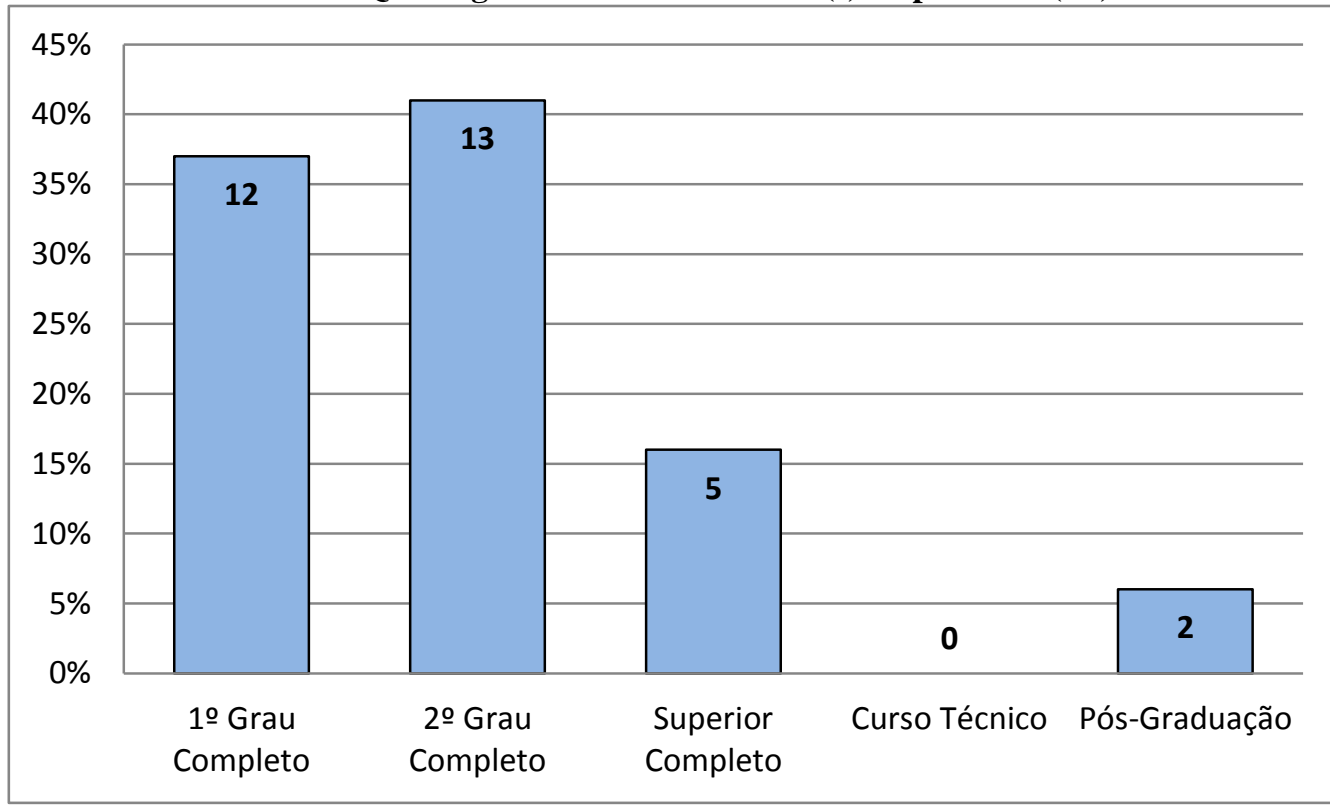

Fonte: Dados da Pesquisa

Dos entrevistados, $78 \%$ declaram terem $1^{\circ}$ ou $2^{\circ}$ grau completo/ensino médio, o que equivale a 25 (vinte e cinco) gestores. 22\% têm alguma graduação ou mais, o que representa apenas 7 (sete) gestores dos trinta e dois entrevistados, demonstrando um baixo nível de escolaridade nos cargos estratégicos da empresa.

Gráfico 4. Já ouviu falar em Contabilidade Gerencial?

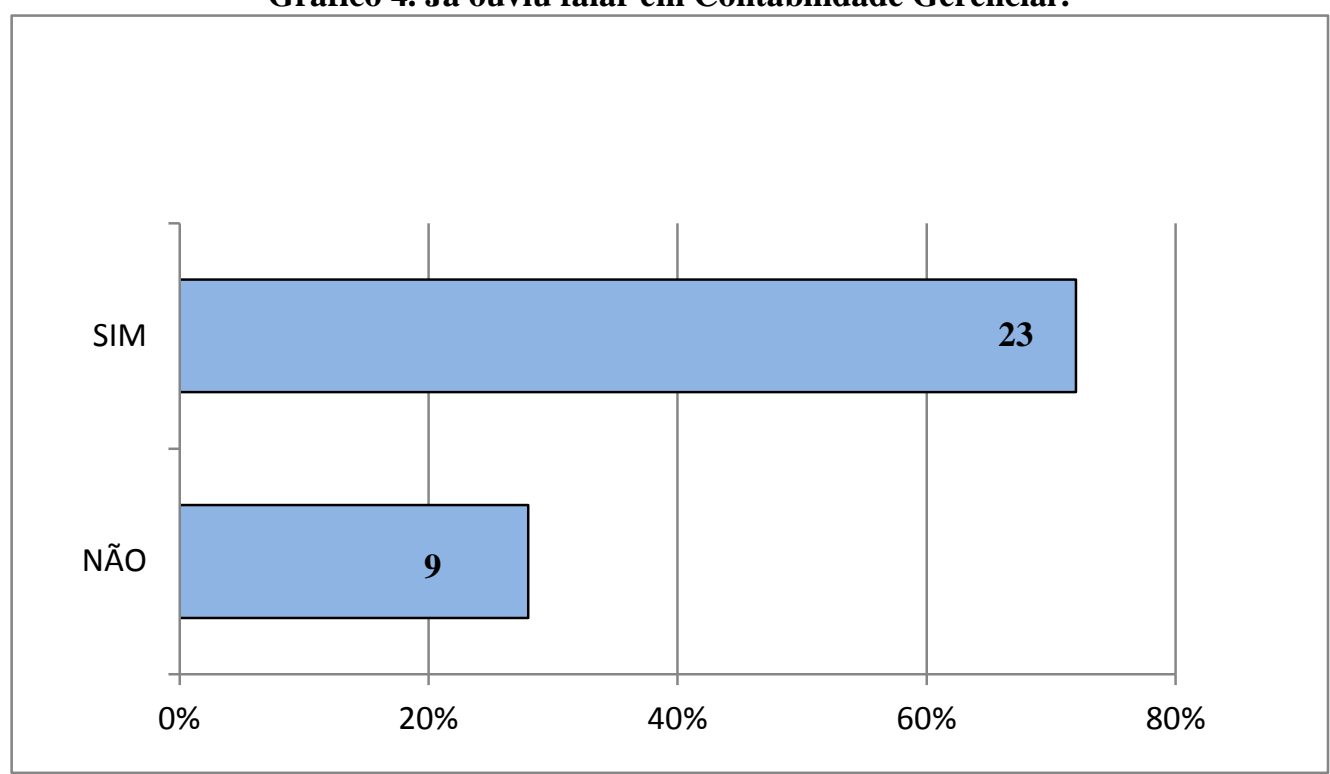


A contabilidade gerencial nas micro e pequenas empresas do comércio de confecções da cidade de Tangará da Serra - MT

César Luís Souto Olyntho; Adervaldo Chaves Ribeiro; Eder Eugenio Munhão

Fonte: Dados da Pesquisa

Os pesquisados foram questionados a respeito de seu conhecimento sobre a Contabilidade Gerencial. $72 \%$ o que é representado por 23 (vinte e três) gestores, responderam que têm conhecimento sobre a Contabilidade Gerencial. Apenas $28 \%$ ou seja, 9 (nove) gestores declararam nunca terem ouvido falar em Contabilidade Gerencial.

Gráfico 5. Faz uso da Contabilidade Gerencial na empresa?

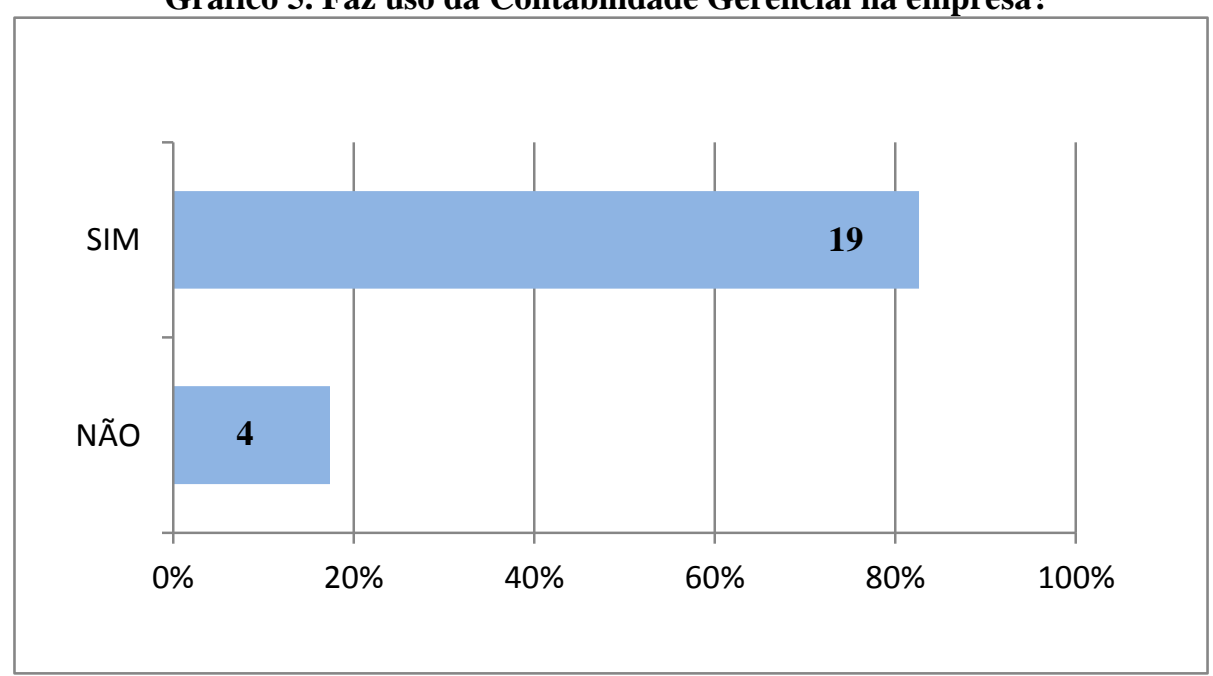

Fonte: Dados da Pesquisa

No Gráfico 5, foi perguntado aos gestores se eles fazem uso da Contabilidade Gerencial em suas empresas, essa questão porém se dirigia apenas aos Gestores que responderam "sim" na questão do Gráfico 4, ou seja, 23 (vinte e três) gestores.

O gráfico 5, demonstra que 83\%, que é representado por 19 (dezenove) gestores, afirmam que utilizam dela em sua empresa e 17\%, ou seja, 4 (quatro) gestores, apesar de terem respondido que ouviram falar a respeito da Contabilidade Gerencial, responderam não fazer uso dela em sua empresa.

Gráfico 6. Como o processo de tomada de decisão na empresa utiliza-se da Contabilidade Gerencial?

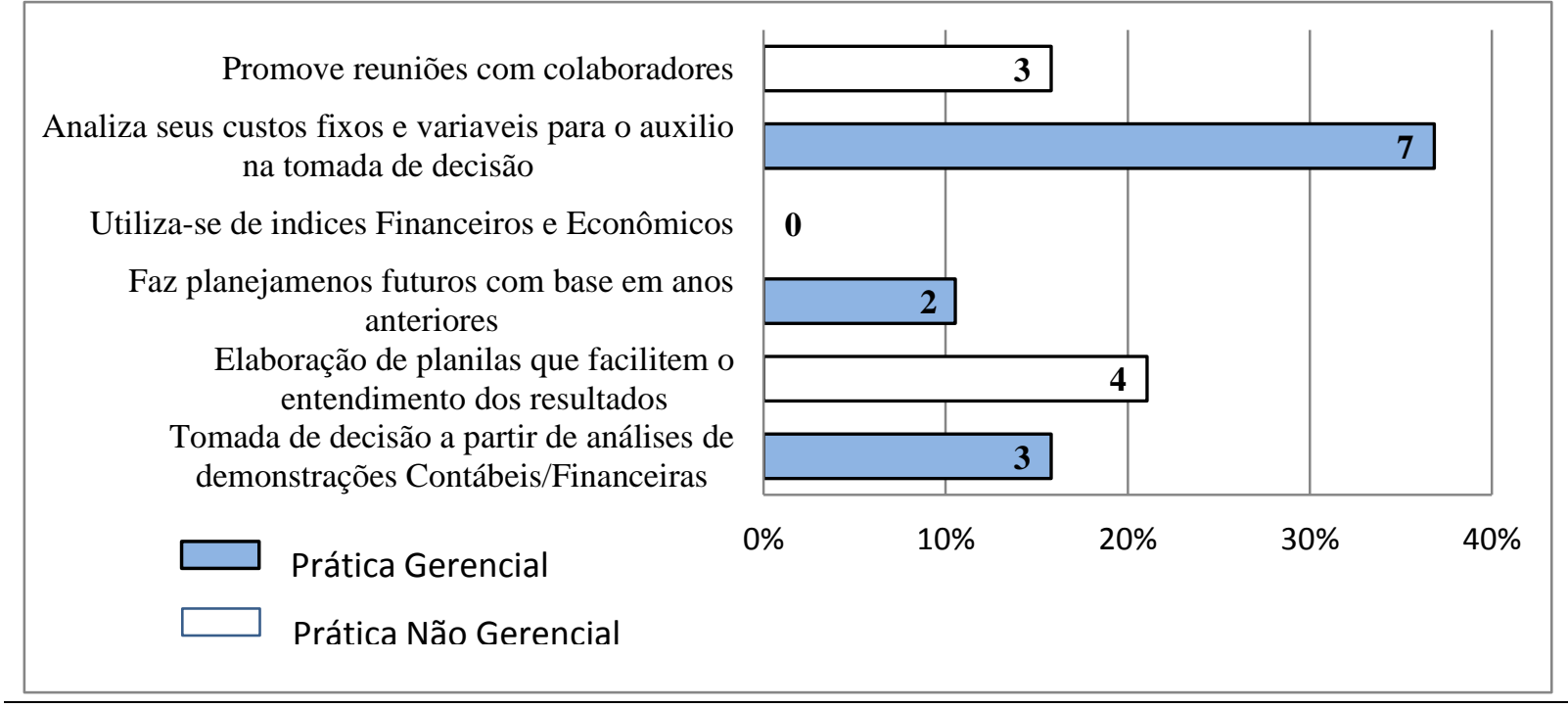


A contabilidade gerencial nas micro e pequenas empresas do comércio de confecções da cidade de Tangará da Serra - MT

César Luís Souto Olyntho; Adervaldo Chaves Ribeiro; Eder Eugenio Munhão

Fonte: Dados da Pesquisa

O Gráfico 6 demonstra o grau de conhecimento dos Gestores com base em alguns processos inerentes ao cotidiano de sua empresa, onde se propõem mostrar se ele conhece realmente algum processo relacionado realmente a Contabilidade Gerencial. O gráfico demonstra seis atividades nas quais, três fazem relação direta com a Contabilidade Gerencial e outras três não. Esta pergunta foi feita para os gestores que responderam "sim" na questão do Gráfico 5, que foram 19 (dezenove).

Foram questionados a respeito da utilização dessa ciência no processo de tomada de decisões na empresa, no qual 37\%, que representam 7 (sete) gestores, responderam que analisam seus custos fixos e variáveis para auxilio na tomada de decisão. 16\%, ou seja, 3 (três) gestores responderam tomar decisões a partir de análises de demonstrações Contábeis/Financeiras e outros $21 \%$ dos gestores, que represente 4 (quatro) deles, declaram elaborar planilhas que facilitem o entendimento dos resultados.

Continuando a análise no Gráfico 6, o resultado foi que, 12 (doze) gestores o que representa 63\%, apontaram alternativas com viés gerencial, ou seja, assinalaram as alternativas 1, 2 ou 4. Por outro lado, 37\% que representam 7 (sete) gestores, apesar de terem respondido que conheciam essa ciência, suas respostas não fazem correlação com a Contabilidade Gerencial, que são as alternativas 3, 5 e 6 do Gráfico 6.

Gráfico 7. Qual o motivo de não utilizar-se da Contabilidade Gerencial?

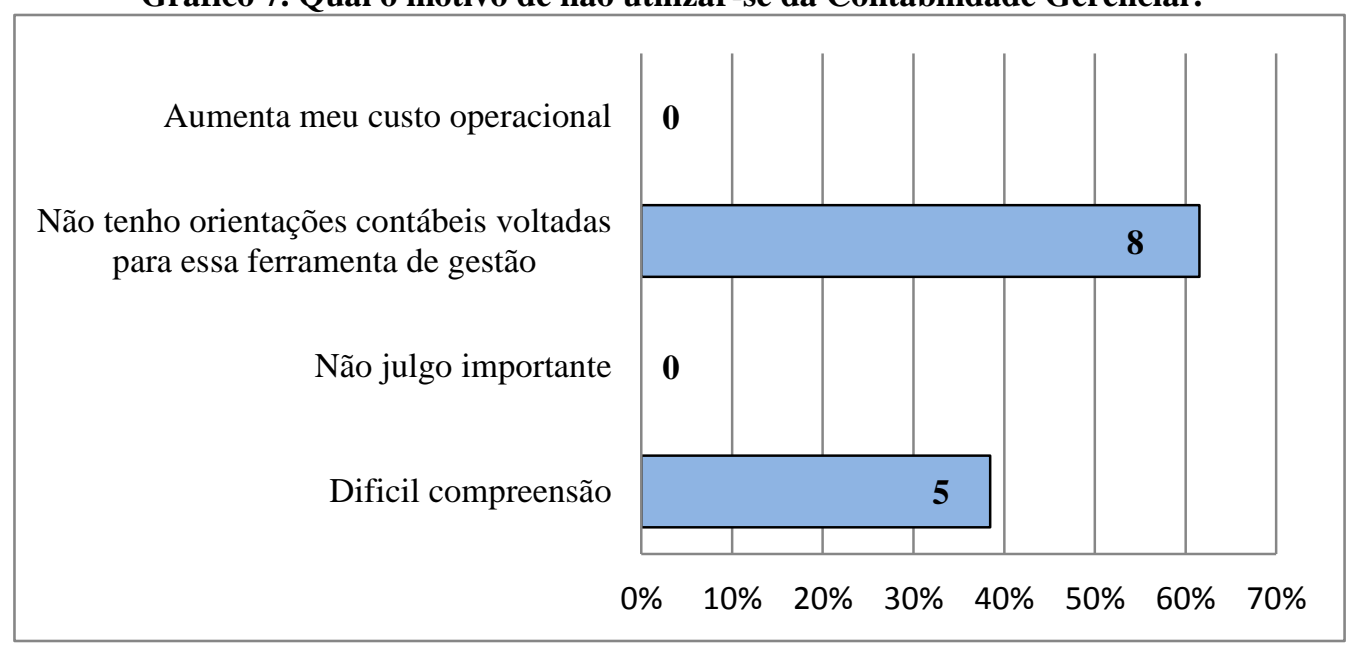

Fonte: Dados da Pesquisa

Na questão do Gráfico 7, foi perguntado o motivo da não utilização da Contabilidade Gerencial em seus processos decisórios, com objetivo de questionar aqueles que responderam “não" para a questão do Gráfico 5 e Gráfico 6, o que representa 13 (treze) gestores.

No Gráfico 7, foi constatado que $62 \%$, ou seja, 8 (oito) gestores não aplicam os fundamentos da Contabilidade Gerencial porque, responderam não ter orientações contábeis 
voltadas para essa ferramenta de gestão e 38\%, que é representado por 5 (cinco) gestores, declararam que não se utilizam por "difícil compreensão". Nenhum gestor considerou o aumento do custo operacional ou a importância, como motivo da não utilização da Contabilidade Gerencial.

Gráfico 8. Recebe suporte como, consultorias, visitas ou orientações a respeito da Contabilidade Gerencial?

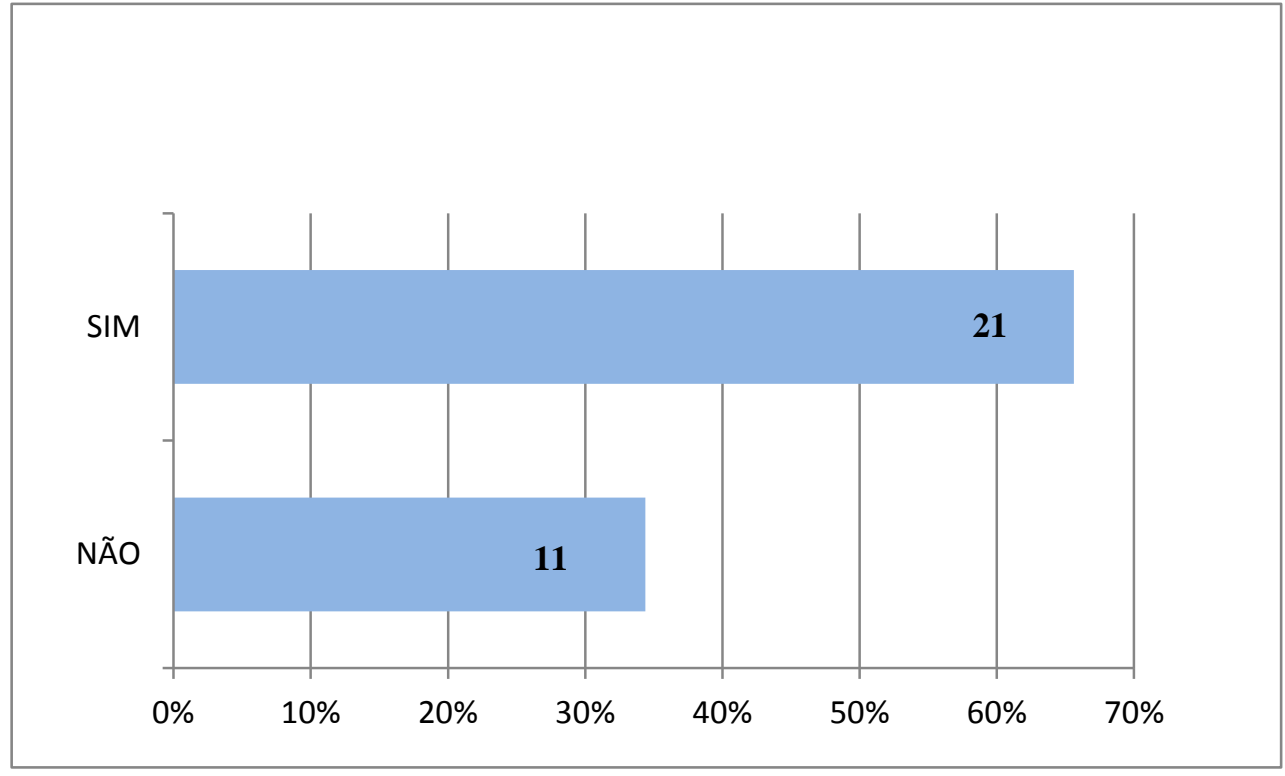

Fonte: Dados da Pesquisa

Como foi demonstrado no Gráfico 7, uma parcela significativa dos entrevistados declararam não terem orientações contábeis voltadas para a Contabilidade Gerencial, no entanto no Gráfico 8, foi feita a seguinte questão "Recebe suporte como, consultorias, visitas ou orientações a respeito da Contabilidade Gerencial?". Assim pode-se notar que 21 (vinte e um) gestores, representando 66\%, afirmam receber periodicamente visitas, orientações ou consultorias a esse respeito e apenas 11 (onze) deles, ou seja, 34\% não recebem ou não buscam essas informações.

O Gráfico 9, leva em consideração apenas o gestores que responderem "sim" na questão do Gráfico 4, ou seja, 23 (vinte e três) gestores. No Gráfico 9, foi questionado aos gestores que fazem uso da Contabilidade Gerencial em sua empresa, que dessem uma nota que variasse de 1 (um) a 10 (dez), em que 1 (um) significa um péssimo aproveitamento da Contabilidade Gerencial e 10 (dez) o aproveitamento de todos os benefícios que ela proporciona à empresa. 9\% ou seja, 2 (dois) gestores, deram uma nota igual ou inferior a 3 (três) pontos e $83 \%$, que corresponde a 19 (dezenove) gestores, deram uma nota igual ou superior a 7 (sete) pontos. De acordo com o resultado, a maioria dos gestores se considera um ótimo usuário da Contabilidade Gerencial. 
A contabilidade gerencial nas micro e pequenas empresas do comércio de confecções da cidade de

Tangará da Serra - MT

César Luís Souto Olyntho; Adervaldo Chaves Ribeiro; Eder Eugenio Munhão

Gráfico 9. Em uma escala de 1 a 10, qual nota você daria para o uso da Contabilidade Gerencial em sua empresa?

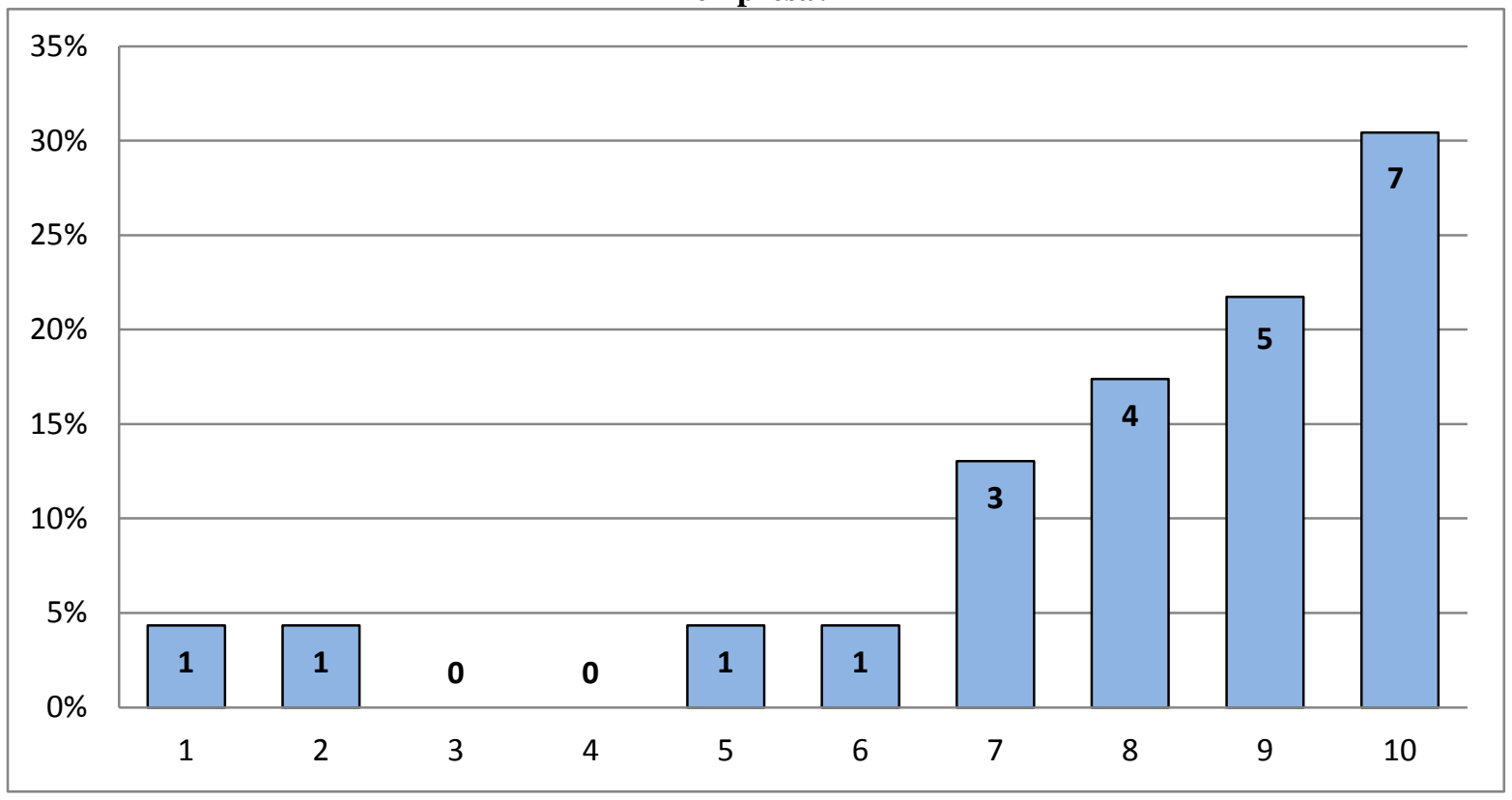

Fonte: Dados da Pesquisa

O Gráfico 10 mostra com detalhes várias atividades desempenhada na maioria das empresas, porém os entrevistados foram questionados a respeito das atividades na qual eles desempenhavam dentro da empresa e ao mesmo tempo, esta atividade deveria ter uma relação com uma atividade gerencial e não apenas uma tarefa aleatória.

Gráfico 10. Dentre estas ações, qual você costuma orientar em sua empresa que e tem relação a Contabilidade Gerencial?

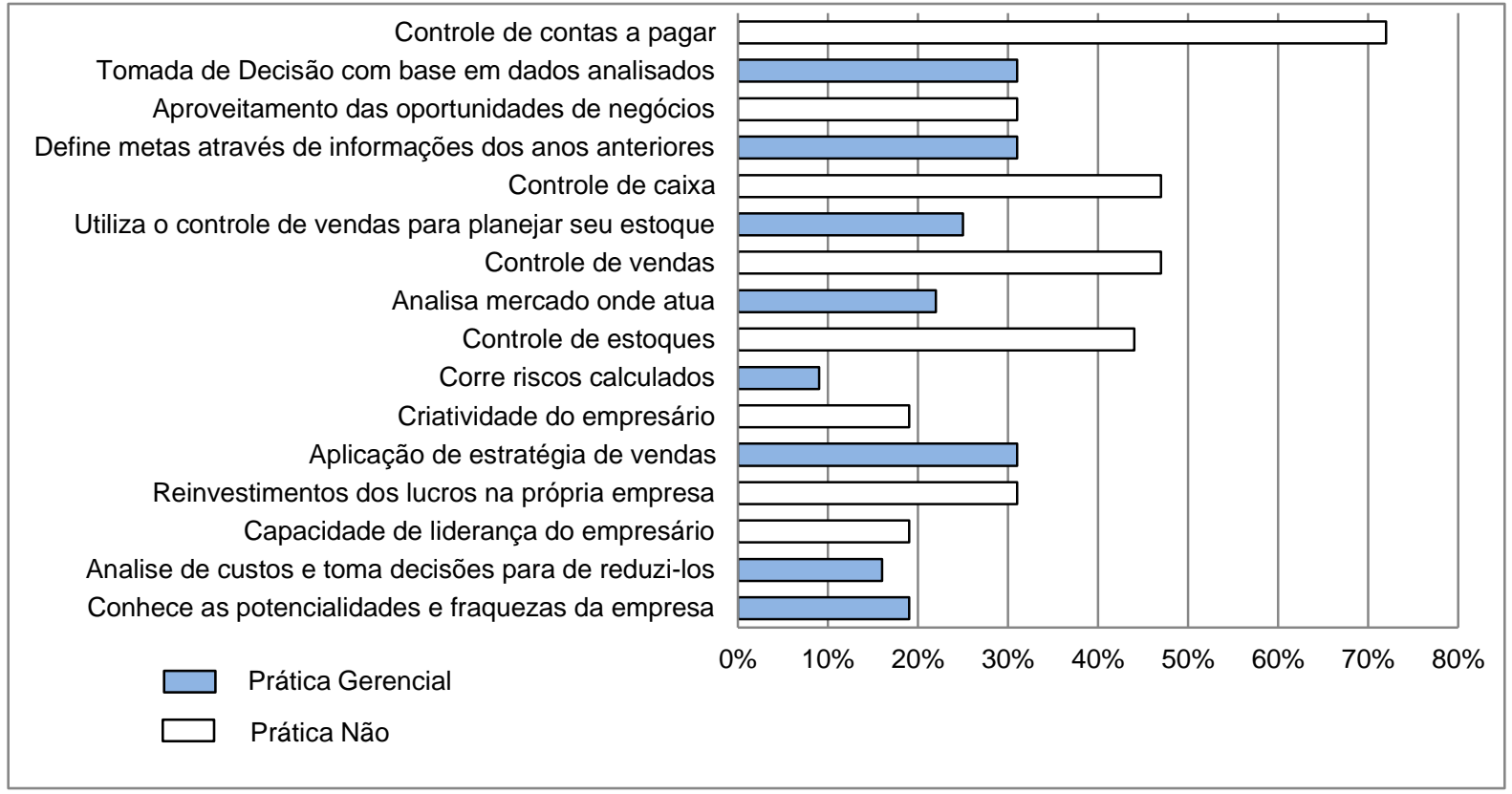

Fonte: Dados da Pesquisa 
A contabilidade gerencial nas micro e pequenas empresas do comércio de confecções da cidade de

Identificou-se conforme o gráfico 10, que as atividades mais desempenhadas pelos gestores, são aquelas que não têm relação direta com a Contabilidade Gerencial, pois são apenas tarefas cotidianas sem uma definição gerencial, quer dizer, elas por si só não constituem um gerenciamento.

Segundo as respostas dos entrevistados, destacam-se 4 (quatro) atividades que para eles, são atividades da Contabilidade Gerencial, são elas "Controle de contas a pagar" 23 (vinte e três) gestores assinalaram essa opção o que representa 72\%. "Controle de caixa" foi assinalado por 15 (quinze) gestores, ou seja, 47\%. "Controle de vendas" também foi respondido por 15 (quinze) gestores, representando então 47\%. "Controle de estoque" foi assinalado por 14 (quatorze) deles o que representa $44 \%$.

Apenas a atividade de controle não é Contabilidade Gerencial, segundo Ricardino (2005, p.9) a Contabilidade Gerencial consiste em fazer um trabalho com riqueza de detalhes dentro da empresa, em que contenha análise, identificação, mensuração, preparação dos resultados e interpretação dos levantamentos, para assim auxiliar os gestores.

Entretanto nota-se, por exemplo, que a atividade "Corre riscos calculados" é assinalada por apenas 3 (três) entrevistados, representando 9\% do total, no entanto ela é uma importante atividade gerencial, pois para desempenhá-la deve-se analisar muitas variáveis e também se faz necessário muitos dados para que o risco seja sempre o menor possível, porém essa atividade foi a menos escolhida.

Gráfico 11. Em que espaço de tempo você costuma analisar seus resultados, por exemplo, relatórios de entradas, saídas, recebimentos, entre outros?

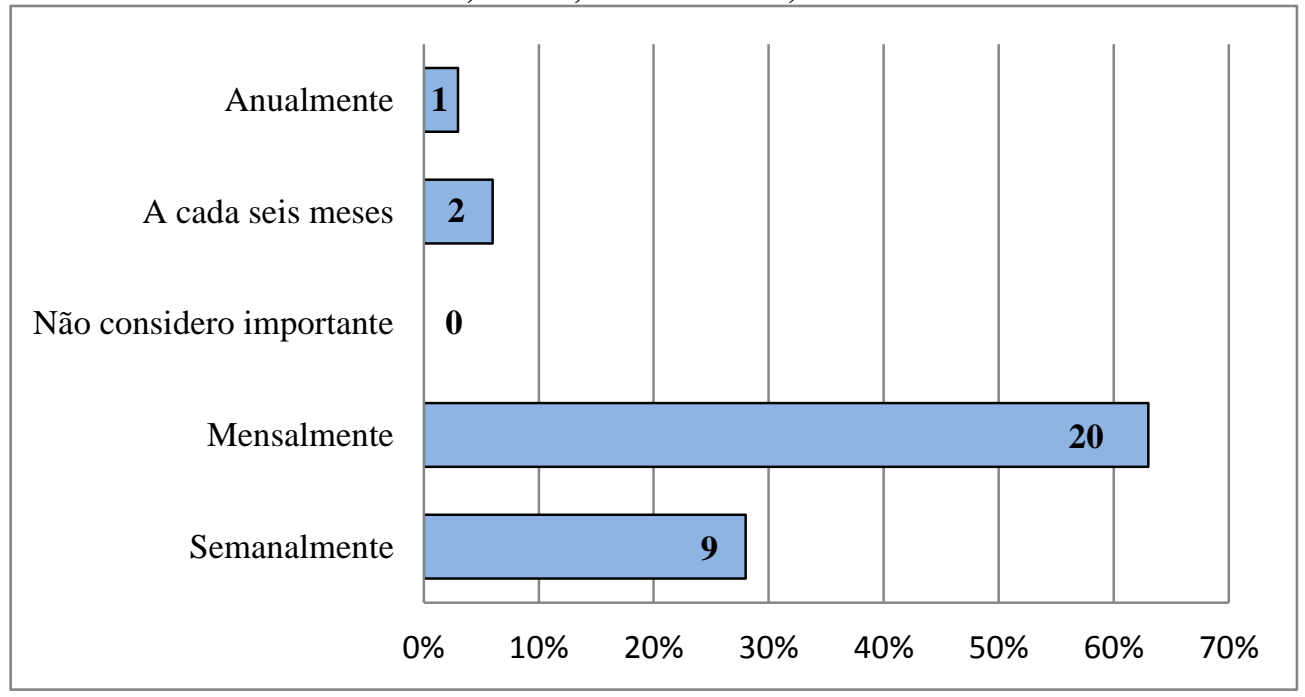

Fonte: Dados da Pesquisa

A respeito do tempo em que o empresário leva para analisar seus relatórios, como Entradas, Saídas, Recebimentos, entre outros, foi identificado e apresentado através do 
A contabilidade gerencial nas micro e pequenas empresas do comércio de confecções da cidade de Tangará da Serra - MT

César Luís Souto Olyntho; Adervaldo Chaves Ribeiro; Eder Eugenio Munhão

Gráfico 11, que 91\% dos gestores, o que representa 29 (vinte e nove) deles, fazem esta análise semanalmente ou mensalmente e $9 \%$ deles, ou seja, 3 (três) gestores, declararam fazer suas análises semestralmente ou anualmente. Nenhum dos entrevistados julgou esta atividade desnecessária.

Os gestores foram questionados a respeito dos planejamentos de curto, médio e longo prazo da empresa, onde poderiam assinalar mais de 1 (um) planejamento, segundo os próprios empresários realmente desempenhavam. Foi determinado com os próprios gestores que planejamento de curto prazo corresponde a 1 (um) período inferior a 1 (um) ano, o de médio prazo vai de um período de 1 (um) a 3 (três) anos e o de longo prazo é superior a 3 (três) anos, segue a Gráfico 12 abaixo.

Gráfico 12. Faz planejamentos de curto, médio e/ou longo prazo na empresa?

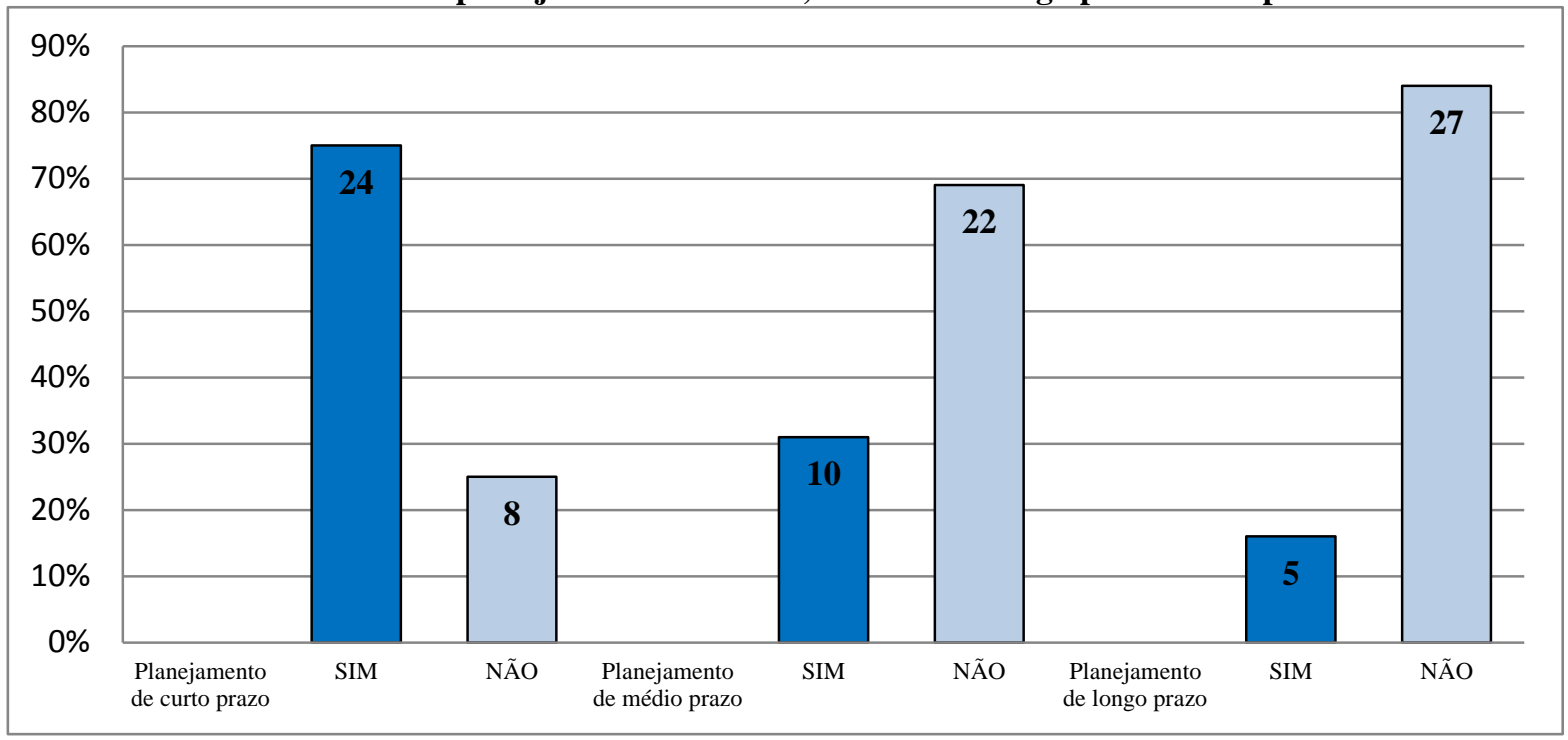

Fonte: Dados da Pesquisa

De acordo com a pesquisa, 24 (vinte e quatro) gestores que representam $75 \%$ dos entrevistados, fazem seu planejamento a curto prazo, o que contrasta-se muito com o planejamento a longo prazo, pois 27 (vinte e sete) gestores, ou seja, 84\% deles afirmam não desempenhá-lo. Isso se dá, segundo os próprios empresários, devido ao comércio de confecções ser um ramo muito dinâmico e com inúmeras oscilações durante um ano, forçando-os a planejarem com um espaço de tempo cada vez menor. 
A contabilidade gerencial nas micro e pequenas empresas do comércio de confecções da cidade de

Tangará da Serra - MT

César Luís Souto Olyntho; Adervaldo Chaves Ribeiro; Eder Eugenio Munhão

Gráfico 13. Quais são os pontos fortes e fracos da empresa?

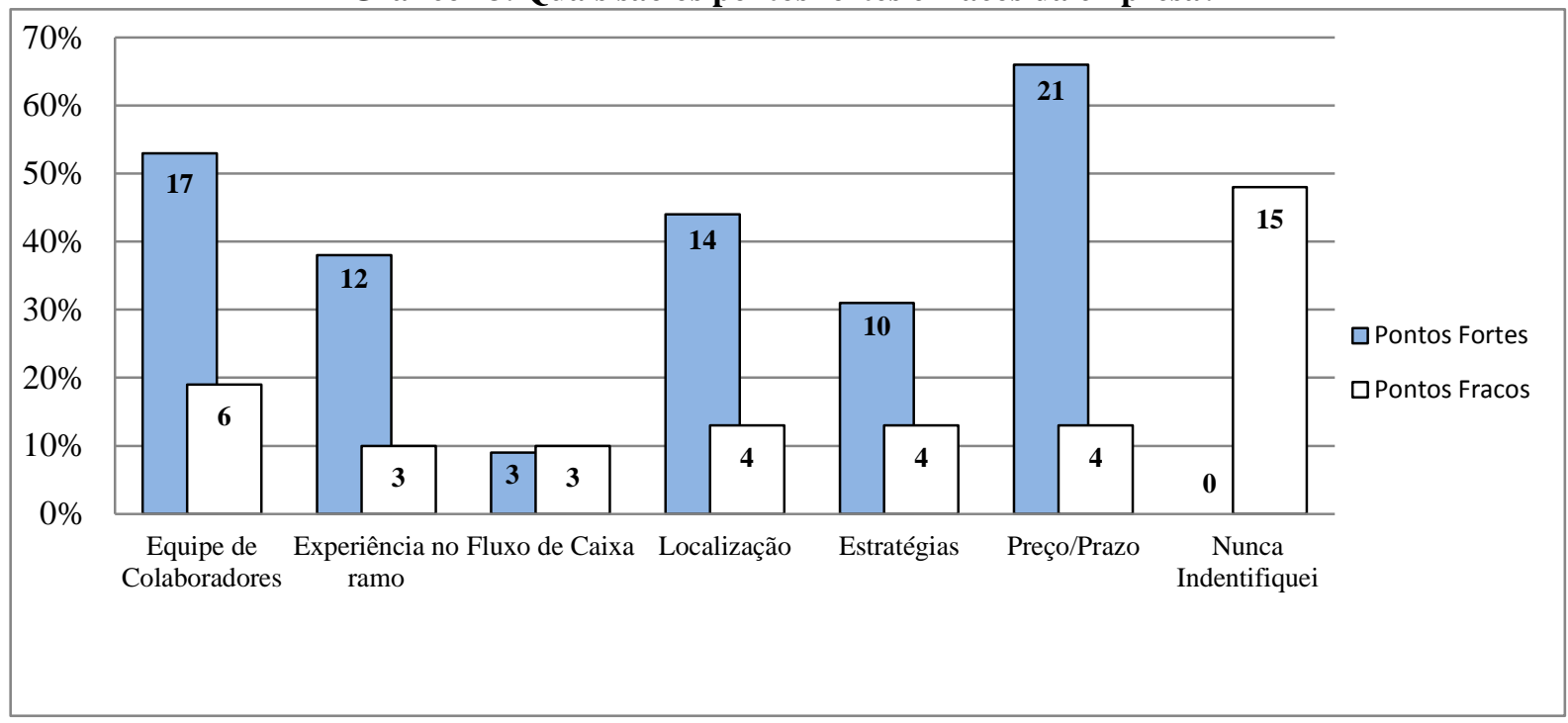

Fonte: Dados da Pesquisa

Foi pedido aos gestores entrevistados, que citassem seus pontos fortes e fracos, 21 (vinte e um) gestores, o que representa $66 \%$ deles, afirmam ter o "preço/prazo" como um ponto forte. 17 (dezessete) gestores, ou seja, 53\% deles citaram "equipe de colaboradores" como maior ponto forte. 14 (quatorze) deles que representam $44 \%$ dos gestores dizem que "localização" é seu ponto forte, nesse caso se dá pelo fato de as empresas entrevistadas se situarem na Avenida Brasil, considerada a principal Avenida de Tangará da Serra - MT.

Com relação aos pontos fracos, 15 (quinze) entrevistados que representam 48\%, declaram não apresentarem sequer um ponto fraco, apenas 4 (quatro) deles, ou seja, 13\%, dizem que "preço/prazo" é um ponto fraco e 6 (seis) gestores que representam 19\%, afirmam que "equipe de colaboradores" é considerada um ponto fraco para a empresa.

\section{CONSIDERAÇÕES FINAIS}

No atual quadro econômico, é de suma importância que as MPE's se solidifiquem no mercado, gerando assim um desenvolvimento na economia local, contribuindo desta forma para o fortalecimento econômico nacional. Para isso é importante demonstrar que a utilização efetiva e objetiva da Contabilidade Gerencial pode e muito, ajudar as empresas em seus processos decisórios.

As MPE's dão uma expressiva contribuição na economia nacional, o que não seria diferente no município de Tangará da Serra - MT, contribuindo para o desenvolvimento da região e para o país.

Porém, é importante ressaltar que as MPE's do comércio de confecções da cidade de Tangará da Serra - MT apresentam índice elevado de mortalidade a partir de seu quarto ano 
de atuação, pois como é mostrado no gráfico 1, há uma maior incidência de empresas, 14 (quatorze), com até 3 (três) anos de existência, e esse numero cai drasticamente para 2 (duas) quando considera-se a idade entre 4 (quatro) à 9 (nove) anos, é uma queda acentuada de 85,72\%. Cujos problemas encontrados são, ausência de conhecimento científico, falta de capital de giro e má gestão administrativo/financeira, que contribuem para que poucas empresas se consolidem no mercado e muitas iniciem suas atividades e fechem após 3 (três) anos.

Esse estudo pesquisou como e por quem é feita a gestão da MPE e se utilizam a Contabilidade Gerencial em suas tomadas de decisões. Por meio de um questionário misto realizado junto aos gestores/proprietários dessas organizações, verificou-se que:

As MPE's do comércio de confecções da cidade de Tangará da Serra - MT em sua maioria, ou seja, como é demonstrado no Gráfico 2, $88 \%$ são administradas por seus proprietários, porém contam com apenas seu conhecimento empírico e não baseiam suas decisões em teses científicas. Como foi pesquisado, conforme Gráfico 3, 79\% dos gestores declaram terem estudado apenas até o $2^{\circ}$ grau/ensino médio, o que delimita o conhecimento desse administrador.

Com relação ao uso da Contabilidade Gerencial nas empresas, fica claro o despreparo com a utilização dessa ciência, pois nota-se no Gráfico 4, que apesar de $72 \%$ dos pesquisados declararem que conhecem a Contabilidade Gerencial, de acordo com o Gráfico 5, 39\% diz não usá-la, isso fica mais evidente quando os gestores são questionados à respeito da utilização dessas práticas gerenciais no Gráfico 10, onde as respostas dadas pelos gestores na maioria das vezes não estão relacionadas com a Contabilidade Gerencial, o que demonstra que apesar de pensarem que conhecem essa ciência, suas respostas os contradizem.

Quando é analisado o Gráfico 10, fica evidenciado que a visão da maioria dos gestores que a Contabilidade Gerencial é uma ferramenta apenas de controle, que existe apenas como uma opção na administração e como foi pesquisado nesse trabalho, a contabilidade gerencial é uma ferramenta útil principalmente no processo de tomada de decisão.

Todo ser humano apresenta pontos fortes e fracos, isso é inerente a qualquer pessoa, o que também não é diferente com as empresas, no entanto no Gráfico 13, 15 (quinze) gestores, ou seja, $48 \%$ dos pesquisados, declararam não conhecerem suas fraquezas. Como as empresas podem responder que aplicam a Contabilidade Gerencial em seu dia-a-dia sem sequer saber apontar um ponto fraco? 
Continuando a respeito do Gráfico 13, ficou evidente que em todas as opções apresentadas, os pontos fortes eram mais apontados que os pontos fracos, apenas isso não define que a empresa necessariamente apresente mais pontos positivos que negativos, isso pode demonstrar que a empresa tenha uma "visão embaçada" de sua realidade, trazendo ao gestor uma impressão particular de que sua administração é eficaz.

É importante ressaltar que esta pesquisa apresenta algumas limitações inerentes à técnica utilizada.

O estudo apresentado, utilizando-se questionário misto, focalizando a utilização da Contabilidade Gerencial em MPE's do comércio varejista de confecções do município de Tangará da Serra - MT, traz a limitação de que seus resultados não podem ser generalizados para outras unidades, objeto e regiões. Como o estudo foi realizado com base na acessibilidade do autor às empresas pesquisadas, o número de empresas pesquisadas, 32 (trinta e duas), também é um fator de limitação quanto aos resultados obtidos. Sendo assim, recomenda-se que futuras pesquisas busquem analisar um maior número de organizações.

\section{SUGESTÕES}

Este estudo demonstra a importância que o gestor domine o conhecimento sobre a Contabilidade Gerencial e aplique essas práticas dentro da empresa, pois ele é o maior interessado que sua empresa se estabeleça no mercado e venha melhorar sua rentabilidade.

O Gestor precisa de dados que possam se transformar em informações, e a partir dai poderão ser analisados e utilizados na tomada de decisão Para que isso ocorra melhor, a participação do contador tem um peso grande, pois é ele que apresentará ao gestor da MPE as demonstrações contábeis, que por se tratarem de micro e pequenas empresas o contador poderá utilizar-se de recursos que facilitem o entendimento do gestor, são elas as demonstrações simplificadas como: Balanço perguntado, DRE adaptada, fluxo de caixa, índices de rentabilidade, etc.

Outras fontes de informações importantes dependerão exclusivamente do gestor, são elas as planilhas de controle, como por exemplo: controle de estoque, de vendas, de contas a pagar, de contas a receber, de custo, entre outras, pois elas precisam ser alimentadas diariamente e corretamente, para que o gestor sempre possa dispor desses recursos.

Sem um controle diário na empresa, o empresário nunca conseguirá aplicar as práticas da Contabilidade Gerencial e em consequência terá uma probabilidade maior da empresas fechar as portas. 
Concluiu-se também com base no Gráfico 7, grande parte dos gestores que não utilizam a Contabilidade Gerencial, o que representa 46,87\% do total dos pesquisados, devido a falta de conhecimento dessa ferramenta de gerenciamento, situação essa que torna impossível uma utilização eficaz e eficiente da Contabilidade Gerencial.

Uma forma de amenizar esse desconhecimento ou o uso equivocado da Contabilidade Gerencial seria uma participação das instituições de ensino, como por exemplo, a Universidade do Estado de Mato Grosso (UNEMAT), SEBRAE, Serviço Nacional de Aprendizagem Comercial (SENAC) que obviamente subsidiadas pelo governo, deveriam dar uma melhor atenção para a disseminação do conhecimento da Contabilidade Gerencial.

\section{REFERÊNCIAS}

ALMEIDA, Martinho Isnard Ribeiro. Desenvolvimento de um modelo de planejamento estratégico para grupos de pequenas empresas. São Paulo: 1994. Tese de Doutorado, FEA/USP.

ATKINSON, Anthony A. BANKER, Rajiv D. KAPLAN, Robert S. YO UNG, S. Mark. Contabilidade Gerencial. Tradução de André Olímpio Mosselman Du Chenoy Castro. Revisão Técnica de Rubens Fama. 2.ed. São Paulo: Atlas, 2000.

BRASIL. MINISTÉRIO DO DESENVOLVIMENTO, INDÚSTRIA E COMÉRCIO EXTERIOR - MDIC. A micro e pequena empresa no Brasil: dados. Brasília, [2000]. Disponível em <http:/www.mdic.gov.br/progacoes-Mpme/Dados/htm>. Acesso em 19/09/2012.

CHILETTO, Eduardo Cairo. 2009: Rede de avaliação e capacitação para a implementação dos planos diretores participativos. Artigo, Disponível em: < http://web.observatoriodasmetropoles.net/planosdiretores/produtos/mt/Relat\%C3\%B3rio\%20 def\%20MT.pdf>: Acesso em: 17 Ago. 2012.

CHING, Yuh Hong. MARQUES, Fernando. PRADO, Lucilene. Contabilidade e Finanças para não especialistas. São Paulo: Pearson Prentice Hall, 2003.

CREPALDI, Silvio Aparecido. Contabilidade Gerencial: teoria e prática. 4. ed. São Paulo: Atlas, 2008.

FRANCIA, Arthur J.; et al. Managerial accounting. 9ª ed. Houston: Dame, 1992.

GUERREIRO, R.; FREZATTI, F.; LOPES, A.B.; PEREIRA, C.A. (2005): O entendimento da Contabilidade Gerencial sob a ótica da teoria institucional. Revista Organizações e Sociedade, V. 12, nº 35, Out./Dez-2005.

IUDÍCIBUS, Sérgio de. Contabilidade Gerencial. 4. Ed., São Paulo : Atlas, 1991. 
KASSAI, Silvia. As empresas de pequeno porte e a contabilidade. Caderno de estudos, FIPECAFI, v.9, n.15, p.60-74, 1997.

KOTLER, Philip. Administração de Marketing: análise, planejamento, implementação e controle. Tradução Ailton Bomfim Brandão. 5. Ed. São Paulo: Atlas, 1998.

LACERDA, Joabe Barbosa. A contabilidade como ferramenta gerencial na gestão financeira das micro e pequenas e médias empresas (MPMEs): Necessidade e aplicabilidade 2003. Disponível em: < http://www.biblioteca.sebrae.com.br/bds/bds.nsf/4D0B9C74BD56C03803257053005D83A 8/\$File/NT000AA6DE.pdf $>$, pesquisado em 15/04/2012

LAURENTINO, Anderson José, et al: A importância da Contabilidade Gerencial para as micro e pequenas empresas no século XXI no Brasil. Trabalho de graduação apresentado à disciplina de Estágio Supervisionado Curso de Ciências Contábeis da FAE Centro Universitário 2008. Disponível em:

<http://www.paranaeducacao.pr.gov.br/arquivos/File/TCC_ANDERSON_DOUGLAS_JOA

O_THIAGO.pdf> Acesso em: 28 abr. 2012.

LUCENA, W. G. L. et. al A Evidenciação das Informações Contábeis Geradas pelas Micro e Pequenas Empresas no Processo Decisório: Um Estudo no Setor de Confecções. REUNIR Revista de Administração, Contabilidade e Sustentabilidade - Vol. 1, no 1, p.35-51, MaiAgo/2011.

MOTA, Renato Henrique Gurgel; REGO, Thaiseany de Freitas. Principais práticas e maiores dificuldades gerenciais das microempresas e empresas de pequeno porte do município de Caraúbas/RN. Artigo Científico, XVI SEMINÁRIO DE PESQUISA DO CCSA ISSN 1808-6381, 2006

PADOVEZE, Clóvis Luís. Contabilidade Gerencial. Um enfoque em sistema de informação contábil. 3. ed. São Paulo: Atlas, 2000.

PANUCCI-FILHO, Laurind; ALMEIDA, Lauro Brito de. A contabilidade gerencial no crescimento das organizações: Um estudo nas Indústrias de confecções 2011. Disponível em:

iberoamericano.org/RICG/N\%C2\%BA\%2018/Laurindo_Panuccci-

Filho_\%20Lauro_Brito.pdf>. Acesso em: 01 Out. 2012

PARENTE, J. Varejo no Brasil. São Paulo: Editora Atlas, 2007.

PRESTES, Maria Luci de Mesquita. A pesquisa e a construção do conhecimento científico: do planejamento aos textos, da escola à academia. $2^{\mathrm{a}}$ ed. São Paulo: Rêspel, 2003.

RICARDINO, Álvaro. Contabilidade Gerencial e Societária: origens e desenvolvimento. São Paulo: Saraiva, 2005. 
SALIM, César Simões; HOCHMAN, Nelson; RAMAL, Andrea Cecilia; RAMAL, Silvina Ana. Construindo planos de negócios: todos os passos necessários para planejar e desenvolver negócios de sucesso. 3. ed. Rio de Janeiro: Elsevier, 2005. 6 Reimpressão.

SCHEFFER, Janaina Rodrigues; CARIO, Silvio A. Ferraz; NICOLAU, José Antônio. Capacitação tecnológica de micro e pequenas empresas em arranjos produtivos locais: um estudo no segmento de materiais plásticos. Florianópolis: UFSC/VIII Encontro de Economia de Região Sul - ANPEC/SUL, 2005.

SEBRAE. Pesquisa dos fatores condicionantes e taxas de sobrevivência e mortalidade das micro e pequenas empresas no Brasil 2003-2005. Brasília, 2007.

SILVA, Silvia Bonfim da. A relevância Contabilidade Gerencial como instrumento de gestão em micro e pequenas empresas. Revista Eletrônica Lato Sensu - Ano 2, n⿳⺈ ${ }^{\circ}$, julho de 2007.

SOUZA, Diocésar Costa. 2008: Evidências de Informações Gerenciais nos Relatórios de Gestão Fiscal da Área Pública. Dissertação de Mestrado, Disponível em: < http://www.ppgcontabilidade.ufpr.br/system/files/documentos/Dissertacoes/D003.pdf> Acesso em: 09 Abr. 2012.

SOUZA, Josiane Aparecida de. A Contabilidade Gerencial como fator determinante à sobrevivência das micro e pequenas empresas. Revista eletrônica Conexão FAISA/FACILUZ 2011, ISSN21780994. Disponível em:

<http://www.conexaofaisafaciluz.com/revista/edicao2/Microsoft $\% 20$ Word $\% 20 \%$ 20CONEX $+\%$ C3\%A2O $\% 20$ FAISA $\% 20$ FACILUZ\%20V.2\%20N.2\%202011\%20\%20CONTABILIDA

D-E\%20GERENCIAL.pdf>, Acesso em 12/04/2012

SOUZA, M.A; LISBOA, L.P.; ROCHA, W. (2003): Práticas de Contabilidade Gerencial adotadas por subsidiárias brasileiras de empresas multinacionais. Revista de Contabilidade e Finanças, USP, São Paulo, nº 32, pp. 40-57, mai./ago.

VERGARA, Sylvia Constant. Projetos e relatórios de pesquisa em administração. 8. ed. São Paulo: Atlas, 2007. 